\title{
PENENTUAN TEKNIK PEMESANAN MATERIAL PADA PROYEK STEEL STRUCTURE MENGGUNAKAN WINQSB
}

\author{
Juliana \\ Program Studi Teknik Informatika, Universitas Indraprasta PGRI \\ Email : kallya_des@yahoo.com
}

\begin{abstract}
Abstrak
Perencanaan persediaan material merupakan salah satu bagian terpenting dalam suatu proyek konstruksi. Keterlambatan dan kehabisan persediaan material mengakibatkan pekerjaan akan tertunda sehingga secara tidak langsung akan mempengaruhi waktu pelaksanaan dan biaya proyek. Dalam perencanaan persediaan material terdapat beberapa teknik lotsizing. Masingmasing teknik akan menghasilkan jumlah pesanan dan frekwensi pesan yang berbeda-beda, yang mengakibatkan perbedaan biaya persediaan yang berbeda pula. Diperlukan penelitian untuk mengetahui teknik lotsizing mana yang menghasilkan biaya persediaan paling minimum. Tujuan utama dari perencanaan dan pengendalian komponen bahan baku ini yaitu agar dapat memjamin kebutuhan komponen bahan baku yang tepat pada saat produk akan di produksi dengan biaya yang serendah-rendahnya. Permasalahan yang ada pada perusahaan adalah, perusahaan masih mengalami kesulitan dalam memanajemen persediaan bahan baku, sehingga terkadang pada saat produk akan diproduksi terdapat kesalahan dalam persediaan komponen bahan baku, sehingga akan melakukan tindakan cepat yang mengakibatkan pengeluaran biaya menjadi lebih tinggi. Dalam melakukan perencanaan persediaan komponen bahan baku ini diantaranya dengan melakukan metode peramalan permintaan produk selama 12 periode mendatang dan membuat rencana kebutuhan bahan baku menggunakan teknik lotting Economic Order Quantity (EOQ), Period Order Quantity dan Part Period Balancing (PPB) dengan menggunakan softwareWINQSB.

Kata Kunci: Lot for Lot, Part Periode Balancing, Economic Order Quantity, Winqsb
\end{abstract}

\section{Pendahuluan}

\section{Latar Belakang}

Pada suatu proyek konstruksi, perencanaan untuk persediaan material merupakan bagian terpenting, karena sumber daya material menyerap hampir sebagian besardari total biaya proyek. Penanganan pengadaan persediaan material tidaklah mudah, pada pelaksanaan pembangunan suatu proyek masih sering dijumpai masalah-masalah yang berkaitan dengan manajemen persediaan material. Kegagalan menggunakan dan menjaga sistem manajemen yang sesuai untuk material konstruksi akan berakibat pada terlambatnya jadwal pelaksanaan proyek dan membengkaknya biaya total. Salah satu sebab dan akibat dari permasalahan tersebut adalah tidak tersedianya bahan atau material pada saat diperlukan. Di latari permasalahan diatas maka dilakukan penelitian ini bertujuan melakukan analisa dalam penentuan ukuran pemesanan material yang dapat membentuk biaya persediaan yang minimal dan mendapatkan teknik lot sizing yang tepat dalam menentukan jumlah pesanan material menggunakan software winqsb.

\section{Tinjauan Pustaka}

\section{Persediaan}

Persediaan adalah bahan atau barang yang harus disediakan atau harus selalu ada baik dalam bentuk bahan jadi, bahan setengah jadi, atau bahan jadi yang disimpan untuk mengikuti permintaan atau kegiatan suatu proyek sehingga dapat menjamin kelancaran proyek itu sendiri.

Faktor-faktor yang mempengaruhi jumlah persediaan material bangunan (Tarore,dkk. 2013) adalah: 1) Perkiraan kebutuhan material bangunan; 2) Daya tahan atau keawetan; 3) Ongkos 
simpan; 4) Resiko penyimpanan 5) Harga material; 6) Kebijaksanaan pembelanjaan; 7) Sulit atau mudah memperoleh material.

\section{Material Requirement Planning (MRP)}

Perencanaan kebutuhan material (MRP) dapat didefinisikan sebagai suatu teknik atau set prosedur yang sistematis untuk penentuan kuantitas serta waktu dalam proses perencanaan dan pengendalian item barang (komponen) yang tergantung pada item- item tingkat (level) yang lebih tinggi (dependent demand). Ada 4 kemampuan yang menjadi ciri utama dari sistem MRP yaitu:

1. Mampu menentukan kebutuhan pada saat yang tepat.

2. Membentuk kebutuhan minimal untuk setiap item.

3. Menentukan pelaksanaan rencana pemesanan.

4. Menentukan penjadwalan ulang atau pembatalan atas suatu jadwal yang sudah direncanakan.

\section{Manfaat Sistem MRP}

Manfaat penggunaan sistem MRP antara lain adalah:

1. Meminimalkan persediaan.

MRP menentukan kapan dan berapa jumlah bahan atau bagian barang yang benar benar dibutuhkan untuk setiap satuan waktu sesuai dengan Jadwal Induk Produksi (JIP), sehingga tingkat sediaan yang berlebihan dapat dihindarkan.

2. Mengurangi resiko keterlambatan produksi atau pengiriman.

MRP mengidentifikasi banyaknya bahan dan komponen yang diperlukan baik dari segi jumlah dan waktunya dengan memperhatikan waktu tenggang produksi maupun pengadaan komponen.

3. Komitmen yang realistis.

Dengan MRP, diharapkan jadwal produksi dapt terpenuhi sesuai dengan rencana, sehingga komitmen terhadap pengiriman barang dilakkukan secara lebih realistis.

4. Meningkatkan efisiensi.

MRP juga mendorong peningkatan efisiensi karena jumlah persediaan, waktu produksi dan waktu pengiriman barang dapat derencakan lebih baik sesuai dengan Jadwal Induk Produksi (JIP).

\section{Lot Sizing}

Dalam perhitungan lot sizing, tersedia berbagai teknik yang terbagi dalam dua kelompok besar, yaitu model lot sizing dinamis dan statis. Penggunaannya tergantung dari kondisi permintaan / pengorderan (planned order release). Bila permintaan bersifat konstan maka model lot sizing statis yang digunakan. Namun apabila permintaan bersifat lumpy, maka model lot sizing dinamis yang harus digunakan.

Beberapa teknik lot sizing adalah:

1. Jumlah Pemesanan Tetap (Fixed Order Quantity)

2. Jumlah Pesanan Ekonomis (Economic Order Quantity)

3. Jumlah Pesanan Atas Dasar Periode (Periode Order Quantity)

4. Lot For Lot

5. Kebutuhan Dengan Periode Tetap (Fixed Period Requirement)

6. Ongkos Unit Terkecil (Least Unit Cost)

\section{Metodologi Penelitian}

\section{Pengumpulan Data}

Data-data yang diperlukan pada penelitian ini adalah data yang berkaitan dengan proyek, yaitu :

1. Gambar proyek

2. Jadwal proyek

3. Jenis material 
4. Kebutuhan material proyek

5. Data-data biaya material proyek

6. Data persediaan material

\section{Tahap dan Prosedur Studi}

Tahapan dalam penelitian ini merupakan urutan langkah secara sistematis dan logis sesuai teori sehingga dapat dilakukan analisis yang akurat sesuai dengan tujuan yang akan dicapai. Tahapan dalam studi ini adalah sebagai berikut:

a. Tahap 1

Melakukan studi literatur untuk mempelajari hal-hal yang berkaitan dengan teknik pemesanan material proyek.

b. Tahap 2

Melakukan pengumpulan data-data yang terkait dengan dengan material proyek steel structure.

c. Tahap 3

Menghitung kebutuhan kotor dan kebutuhan bersih material proyek steel structure yang diteliti.

d. Tahap 4

Menentukan ukuran lot dan jadwal pemesanan material dengan menggunakan teknik lot for lot, EOQ, dan PPB.

e. Tahap 5

Menghitung biaya total persediaan material proyek.

f. Tahap 6

Penarikan kesimpulan dan saran terhadap hasil tahapan yang telah dilakukan. 
Bagan Alir Penulisan

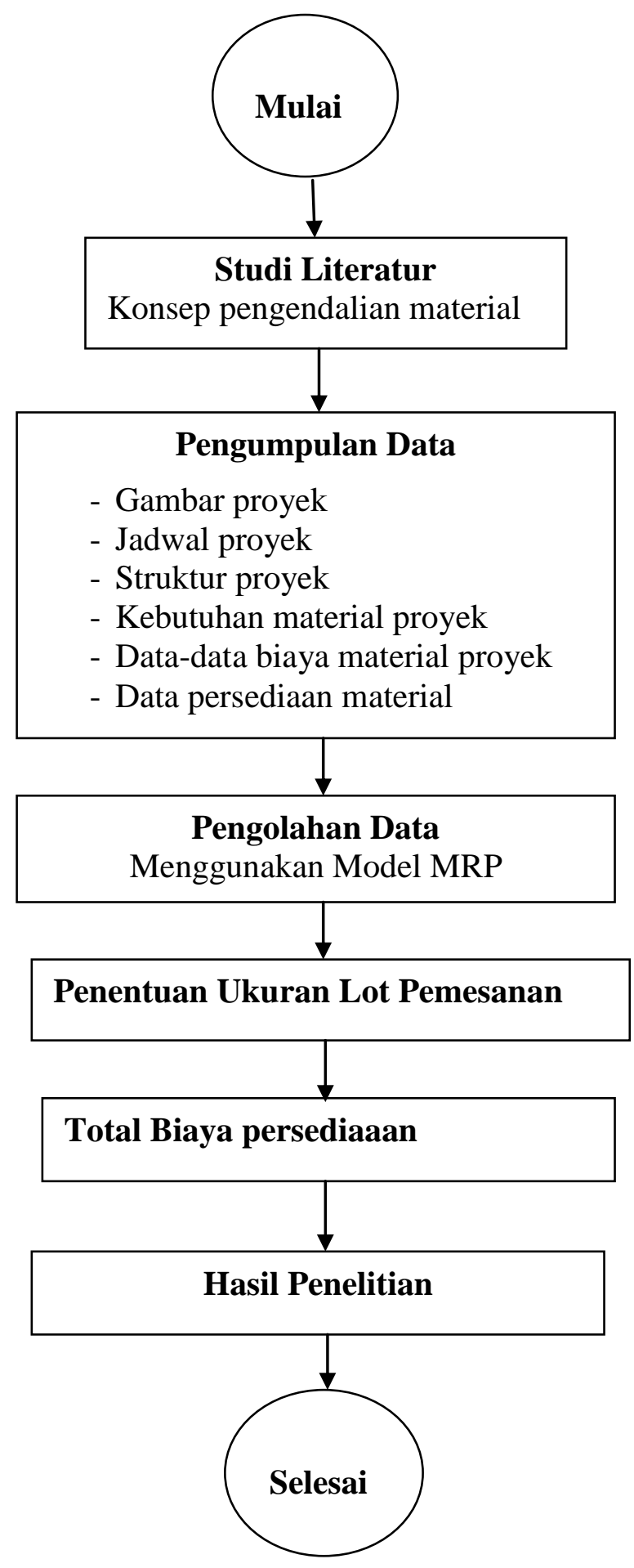

Gambar 1. Bagan Alir Penelitian 


\section{Hasil dan Pembahasan}

\section{Analisa Data Mengunakan WINQSB}

Dalam bab ini dibahas hasil yang telah di capai hingga saat ini, serta hambatan yang di temui selama pengerjaan penelitian. Gambar- gambar berikut menjelaskan tahapan - tahapan analisa data yang telah dilakukan dalam penelitian ini.

Tabel 1. Item Master

\begin{tabular}{|c|c|c|c|c|c|c|c|c|c|c|c|c|}
\hline No. & $\begin{array}{l}\text { item } \\
\text { I.D }\end{array}$ & $\begin{array}{l}\text { ABC } \\
\text { Class }\end{array}$ & $\begin{array}{l}\text { Source } \\
\text { Code }\end{array}$ & $\begin{array}{l}\text { Material } \\
\text { Type }\end{array}$ & $\begin{array}{l}\text { Unit } \\
\text { Measure }\end{array}$ & $\begin{array}{l}\text { Lead } \\
\text { Time }\end{array}$ & $\begin{array}{l}\text { Lot } \\
\text { Size }\end{array}$ & $\underset{\%}{\text { Scrap }}$ & $\begin{array}{l}\text { Unit } \\
\text { Cost }\end{array}$ & $\begin{array}{l}\text { Setup } \\
\text { Cost }\end{array}$ & $\begin{array}{r}\text { Holding } \\
\text { Annual } \\
\text { Cost } \\
\end{array}$ & $\begin{array}{r}\text { Shorthage } \\
\text { Annual } \\
\text { Cost } \\
\end{array}$ \\
\hline 1 & A & & & Besi & $\mathrm{kg}$ & 2 & LFL & & 500 & 200 & 150 & $\mathrm{M}$ \\
\hline 2 & B & & & Besi & $\mathrm{kg}$ & 2 & LFL & & 500 & 200 & 150 & $\mathrm{M}$ \\
\hline 3 & C & & & Besi & $\mathrm{kg}$ & 1 & LFL & & 50 & 200 & 10 & $\mathrm{M}$ \\
\hline 4 & D & & & Besi & pcs & 1 & LFL & & 50 & 200 & 10 & $\mathrm{M}$ \\
\hline 5 & E & & & Besi & pcs & 1 & LFL & & 50 & 200 & 10 & $\mathrm{M}$ \\
\hline 6 & $\mathrm{~F}$ & & & Besi & $\mathrm{kg}$ & 2 & PPB & & 500 & 200 & 150 & $\mathrm{M}$ \\
\hline 7 & G & & & Besi & $\mathrm{kg}$ & 2 & PPB & & 500 & 200 & 150 & M \\
\hline 8 & $\mathrm{H}$ & & & Besi & $\mathrm{kg}$ & 2 & PPB & & 500 & 200 & 150 & $\mathrm{M}$ \\
\hline 9 & I & & & Besi & $\mathrm{kg}$ & 2 & LFL & & 500 & 200 & 150 & $\mathrm{M}$ \\
\hline 10 & $\mathrm{~J}$ & & & Besi & $\mathrm{kg}$ & 2 & LFL & & 500 & 200 & 150 & $\mathrm{M}$ \\
\hline 11 & K & & & Besi & $\mathrm{kg}$ & 2 & LFL & & 500 & 200 & 150 & $\mathrm{M}$ \\
\hline 12 & $\mathrm{~L}$ & & & Besi & pcs & 1 & LFL & & 50 & 25 & 10 & M \\
\hline 13 & M & & & Besi & $\mathrm{kg}$ & 2 & PPB & & 500 & 200 & 150 & $\mathrm{M}$ \\
\hline 14 & $\mathrm{~N}$ & & & Besi & $\mathrm{kg}$ & 2 & LFL & & 500 & 200 & 150 & M \\
\hline 15 & O & & & Besi & $\mathrm{kg}$ & 2 & LFL & & 500 & 200 & 150 & $\mathrm{M}$ \\
\hline 16 & $\mathrm{P}$ & & & Besi & $\mathrm{kg}$ & 2 & LFL & & 500 & 200 & 150 & M \\
\hline 17 & Q & & & Besi & $\mathrm{kg}$ & 2 & LFL & & 500 & 200 & 150 & M \\
\hline 18 & $\mathrm{R}$ & & & Besi & $\mathrm{kg}$ & 2 & LFL & & 500 & 200 & 150 & M \\
\hline 19 & S & & & Besi & $\mathrm{kg}$ & 2 & LFL & & 500 & 200 & 150 & M \\
\hline 20 & $\mathrm{~T}$ & & & Besi & $\mathrm{kg}$ & 2 & PPB & & 500 & 200 & 150 & M \\
\hline 21 & $\mathrm{U}$ & & & Besi & $\mathrm{kg}$ & 2 & LFL & & 500 & 200 & 150 & $\mathrm{M}$ \\
\hline 22 & $\mathrm{~V}$ & & & Besi & $\mathrm{kg}$ & 2 & LFL & & 500 & 200 & 150 & M \\
\hline 23 & W & & & Besi & $\mathrm{kg}$ & 2 & LFL & & 500 & 200 & 150 & M \\
\hline 24 & $\mathrm{X}$ & & & Besi & $\mathrm{kg}$ & 2 & LFL & & 500 & 200 & 150 & M \\
\hline 25 & Y & & & Besi & pcs & 1 & LFL & & 500 & 200 & 150 & M \\
\hline 26 & Z & & & Besi & $\mathrm{kg}$ & 2 & PPB & & 50 & 25 & 10 & M \\
\hline 27 & $\mathrm{AA}$ & & & Besi & $\mathrm{kg}$ & 2 & PPB & & 500 & 200 & 150 & M \\
\hline 28 & $\mathrm{BB}$ & & & Besi & $\mathrm{kg}$ & 2 & PPB & & 500 & 200 & 150 & M \\
\hline 29 & $\mathrm{CC}$ & & & Besi & $\mathrm{kg}$ & 2 & PPB & & 500 & 200 & 150 & M \\
\hline 30 & $\mathrm{DD}$ & & & Besi & $\mathrm{kg}$ & 2 & LFL & & 500 & 200 & 150 & M \\
\hline 31 & $\mathrm{EE}$ & & & Besi & $\mathrm{kg}$ & 2 & LFL & & 500 & 200 & 150 & $\mathrm{M}$ \\
\hline 32 & $\mathrm{FF}$ & & & Besi & $\mathrm{kg}$ & 2 & LFL & & 500 & 200 & 150 & M \\
\hline 33 & GG & & & Besi & $\mathrm{kg}$ & 2 & LFL & & 500 & 200 & 150 & $\mathrm{M}$ \\
\hline 34 & $\mathrm{HH}$ & & & Besi & $\mathrm{kg}$ & 2 & PPB & & 500 & 200 & 150 & $\mathrm{M}$ \\
\hline
\end{tabular}


Pada tahap item master di perlukan input berupa item-item material apa saja yang ada, bahan material, satuan unit material, dan teknik loting yang di gunakan bisa berupa LFL, PPB atau EOQ.

\begin{tabular}{|c|c|c|c|c|c|c|c|c|c|c|}
\hline $\begin{array}{c}\text { item } \\
1 . D \\
\end{array}$ & $\begin{array}{c}\text { Overdue } \\
\text { Requirement }\end{array}$ & $\begin{array}{c}\text { Week } 1 \\
\text { Requirement }\end{array}$ & $\begin{array}{c}\text { Week } 2 \\
\text { Requirement } \\
\end{array}$ & $\begin{array}{c}\text { Week } 3 \\
\text { Requirement }\end{array}$ & $\begin{array}{c}\text { Week } 4 \\
\text { Requirement }\end{array}$ & $\begin{array}{c}\text { Week } 5 \\
\text { Requirement } \\
\end{array}$ & $\begin{array}{c}\text { Week } 6 \\
\text { Requirement }\end{array}$ & $\begin{array}{c}\text { Week } 7 \\
\text { Requirement } \\
\end{array}$ & \begin{tabular}{|c|} 
Week 8 \\
Requirement \\
\end{tabular} & $\begin{array}{c}\begin{array}{c}\text { Week } \\
\text { Requirerr }\end{array} \\
\end{array}$ \\
\hline A & & 1020 & & & & & & & & \\
\hline B & & 335 & & & 295 & & & 265 & & \\
\hline C & & 180 & 147 & 24 & 32 & & 168 & & & \\
\hline D & & & 558 & & & 716 & & & & \\
\hline E & & 8 & & & & & & & & \\
\hline $\mathbf{F}$ & & & 65 & & & 15 & & & & \\
\hline G & & & & 200 & & & 200 & & & \\
\hline $\mathrm{H}$ & & & 705 & & & & 1040 & & & \\
\hline 1 & & & & 895 & & & & 500 & & \\
\hline $\mathrm{J}$ & & & 3177 & & & & & 110 & & \\
\hline $\mathrm{K}$ & & & & & & 128 & & 184 & & \\
\hline L & & & & 336 & & & 332 & & & \\
\hline $\mathrm{M}$ & & & 965 & & & & 1475 & & & \\
\hline $\mathrm{N}$ & & & & 695 & & & & 690 & & \\
\hline 0 & & & & & 900 & & 715 & & & \\
\hline $\mathbf{P}$ & & & 105 & & & 100 & & & & \\
\hline Q & & & 75 & & & 35 & & & & \\
\hline$R$ & & & & 333 & & & & 318 & & \\
\hline$s$ & & & & & & 15 & & & & \\
\hline$T$ & & & & & & 315 & & & & \\
\hline$u$ & & & & & 1200 & & & 1295 & & \\
\hline $\mathrm{v}$ & & & & & 72 & & & 73 & & \\
\hline$w$ & & & & & & 69 & & & & \\
\hline$x$ & & & & 44 & & & & 65 & & \\
\hline$Y$ & & & 8 & & & 8 & & & & \\
\hline$z$ & & & 230 & & & & 70 & & & \\
\hline AA & & & & 235 & & & & 35 & & \\
\hline BB & & & 420 & & & & 70 & & & \\
\hline $\mathrm{CC}$ & & & & 440 & & & & & & \\
\hline $\mathrm{DD}$ & & & & 1190 & & & 1765 & & & \\
\hline EE & & & 1395 & & & & 1240 & & & \\
\hline $\mathrm{FF}$ & & & & 695 & & & & 620 & & \\
\hline
\end{tabular}

Gambar 2. Master Production Schedulle

Gambar di atas menjelaskan tentang kebutuhan material per minggunya. Data di input berdasarkan kebutuhan material proyeknya. Terdapat 34 item untuk kebutuhan proyek Steel Structure. 


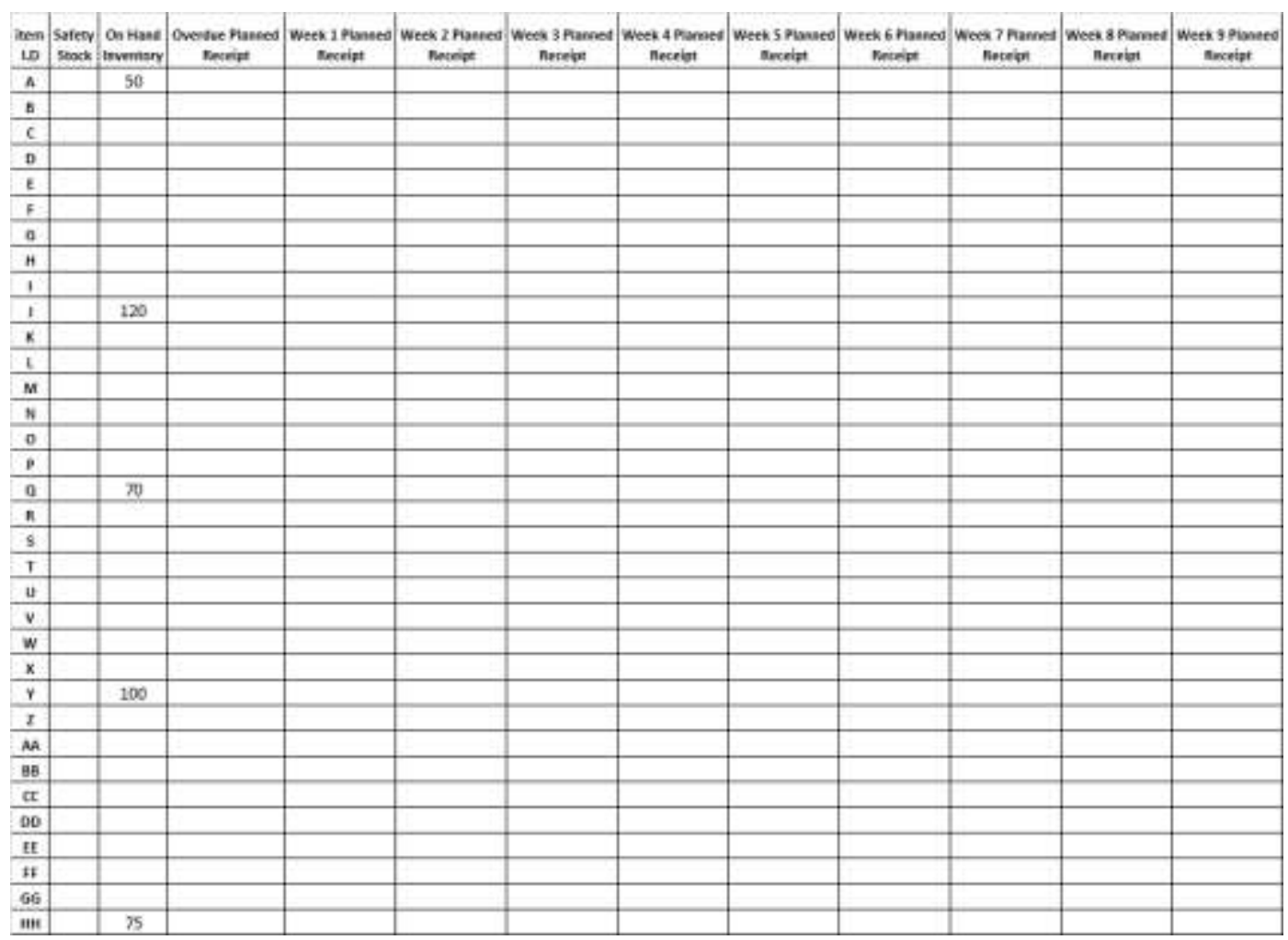

Gambar 3. Status Inventory

Pada tahap ini di masukkan data persediaan material yang tersedia, apabila tidak ada ada stok maka di kosongkan. Data inventory ini akan di gunakan pada waktu pemesanan material. 


\begin{tabular}{|c|c|c|c|c|c|c|c|c|c|c|c|}
\hline $07-19-2-16$ & Overdve & Week 1 & Week. 2 & Week 3 & Week 4 & Week 5 & Week 6 & Week? & Week 8 & Wrek? & Toeat \\
\hline teem: A & & $L T=2$ & $55=0$ & $15=L F L$ & $U M=k g$ & $A B C=$ & Source $=$ & Type $=$ Besi & A. Demand $=0$ & @Cost $=500$ & SetupCost $=200$ \\
\hline Gross Requirement & 970 & 1.020 & 0 & 0 & 0 & 0 & 0 & 0 & 0 & 0 & 1.990 \\
\hline Schesulle Rectipt & 요 & o & 0 & 0 & 0 & 0 & 0 & 0 & 0 & 0 & 0 \\
\hline Projected On Hand & 50 & 0 & 0 & 0 & 0 & 0 & 0 & 0 & 0 & 0 & \\
\hline Projected Nion Requirement & 0 & 970 & 0 & 0 & 0 & o. & 0 & o. & 0 & c) & 970 \\
\hline Planned Order Reteipt & 0 & 970 & 0 & 0 & 0 & 0 & 0 & ㅇ. & 0 & 0 & 970 \\
\hline Planed Order Reiease & 970 & 0 & 0 & 0 & 0 & 0 & 0 & 0 & $\overline{0}$ & 0 & 970 \\
\hline & & & & & & & & & & & \\
\hline $\operatorname{trem}: B$ & & $L T=2$ & $S S=0$ & $L S=L F L$ & $U M=\mathrm{kg}_{\mathrm{g}}$ & $A B C=$ & Source $=$ & Type $=$ Besi & A. Demand $=0$ & $@ \cos t=500$ & SetupCost $=200$ \\
\hline Gross Rieepirement & 335 & 335 & 295 & 0 & 295 & 265 & 0 & 265 & 0 & 0 & 1.790 \\
\hline Scheofulle Receipt & 0 & 요 & 0 & 0 & 0 & 0 & 0 & 0 & 0 & 0 & $\underline{0}$ \\
\hline Projected On Hand & o) & o & 0 & 0 & 0 & 0. & o & 0 & 0 & 0 & \\
\hline Projected Not llequirement & 0 & 335 & 0 & 0 & 295 & 0 & 0 & 265 & $\underline{0}$ & 0 & 895 \\
\hline Planed Ovder Recelot & 0 & 335 & 0 & 0 & 295 & 0 & 0 & 265 & 0 & o & 895 \\
\hline Plannet Ordes Release & 335 & 0 & 295 & 0 & 0 & 265 & 0 & 0 & 0 & 0 & 895 \\
\hline & & & & & & & & & & & \\
\hline Item: $C$ & & $\mathrm{LT}=2$ & $55=0$ & IS $=$ LFL & $U M=\mathrm{kg}$ & $A B C=$ & Source * & Trpe * Beși & A. Demand $=0$ & $@$ Cost $=500$ & SetupCost $=200$ \\
\hline Geoss Requirement & 180 & 327 & 171 & 56 & 32 & 168 & 168 & 0 & $\underline{0}$ & 0 & 1.102 \\
\hline Schesulle Rectipt & 0 & 0 & 0 & 0 & 0 & 0 & 0 & 0 & 0 & 0 & 0 \\
\hline Projected On Hand & 0 & 0 & 0 & 0 & 0 & 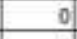 & 0 & ㅇ. & $\underline{0}$ & 0 & \\
\hline Projected Not Requirement & o) & 180 & 147 & 24 & 32 & 0. & 168 & 0. & 0 & 0 & 551 \\
\hline Planned Order fleceipt & 0 & 180 & 147 & 24 & 32. & 0 & 168 & 0 & 0 & 0 & 551 \\
\hline Planed Onder Release & 180 & 147 & 24 & 32. & 요 & 168 & 0 & 0. & 0 & 0 & 551 \\
\hline trem: D & & $L T=2$ & $S S=0$ & $L S=L F L$ & $U M=\mathrm{kg}$ & $A B C=$ & Source $=$ & Type $=$ Besi & A. Demand $=0$ & $\Phi \operatorname{Cos} t=500$ & SetupCost $=200$ \\
\hline Gross fleqwirement & 0 & 558 & 558 & 0 & 716 & 716 & 0 & 0 & 0 & 0 & 2.548 \\
\hline Scheosille Receipt & 0 & 0 & 0 & 0 & 의 & 0 & 0 & ㅇ. & 0 & 0 & 0 \\
\hline Projected On Mane & 의 & 0 & 0 & 0 & 0 & 0 & 0 & 0 & 0 & 0 & \\
\hline Projected Not Hequirement & 0 & 요 & 558 & 0 & 0 & 716 & 0 & ㅇ․ & $\underline{0}$ & 0 & 1.274 \\
\hline Planened Order Receigr & 요 & 0 & 558 & 0 & 0 & 716 & 0 & a. & 0 & 0 & 1.274 \\
\hline Planned Order thelesse & 0) & 558 & 0 & 0 & 716 & 0 & 0 & 0 & 0 & 0 & 1.274 \\
\hline & & & & & & & & & & & \\
\hline ttem:E & & $L T=2$ & $5 S=0$ & $L 5=L F L$ & $U M=k g$ & $A B C=$ & Source : & Type $=$ Besi & A. Demand $=0$ & $@ \operatorname{Cos} t=500$ & SetupCost $=200$ \\
\hline Gross Reguirement & 8 & 8 & 0 & 0 & 0 & 0 & 0 & 0 & 0 & 0 & 16 \\
\hline Schesulle Restipt & 0 & 0 & 0 & 0 & 0 & 0 & 0 & 0 & 0 & 0 & 0 \\
\hline Projected On Hand & 0 & 0 & 0 & 0 & 0] & 0 & 0 & 0 & 0 & 0 & \\
\hline
\end{tabular}

\section{Gambar 4. MRP Report}

Pada gambar 4 di atas, di ketahui bahwa untuk item B diperlukan total material sebanyak $895 \mathrm{Kg}$. Total pemesanan sebanyak 3 kali menggunakan teknik LFL. Pemesanan di lakukan pada minggu persiapan sebanyak $335 \mathrm{~kg}$, minggu ke -2 sebanyak $295 \mathrm{~kg}$, dan minggu ke -5 $365 \mathrm{~kg}$. 


\begin{tabular}{|c|c|c|c|c|c|c|c|c|c|c|c|c|}
\hline $07-19-2-16$ & item I.D & Overdue & Week 1 & Week 2 & Week 3 & Week 4 & Week 5 & Week 6 & Week 7 & Week 8 & Week 9 & Total \\
\hline 1 & A & 970 & 0 & 0 & 0 & 0 & 0 & 0 & 0 & 0 & 0 & 970 \\
\hline 2 & $\mathrm{~B}$ & 335 & 0 & 295 & 0 & 0 & 265 & 0 & 0 & 0 & 0 & 895 \\
\hline 3 & C & 180 & 147 & 24 & 32 & 0 & 168 & 0 & 0 & 0 & 0 & 551 \\
\hline 4 & D & 0 & 558 & 0 & 0 & 716 & 0 & 0 & 0 & 0 & 0 & 1.274 \\
\hline 5 & $\mathrm{E}$ & 8 & 0 & 0 & 0 & 0 & 0 & 0 & 0 & 0 & 0 & 8 \\
\hline 6 & $\mathrm{~F}$ & 65 & 0 & 0 & 15 & 0 & 0 & 0 & 0 & 0 & 0 & 80 \\
\hline 7 & G & 0 & 200 & 0 & 0 & 200 & 0 & 0 & 0 & 0 & 0 & 400 \\
\hline 8 & $\mathrm{H}$ & 705 & 0 & 0 & 0 & 1.040 & 0 & 0 & 0 & 0 & 0 & 1.745 \\
\hline 9 & 1 & 0 & 895 & 0 & 0 & 0 & 500 & 0 & 0 & 0 & 0 & 1.395 \\
\hline 10 & $\mathrm{~J}$ & 3.057 & 0 & 0 & 0 & 0 & 110 & 0 & 0 & 0 & 0 & 3.167 \\
\hline 11 & K & 0 & 0 & 0 & 128 & 0 & 184 & 0 & 0 & 0 & 0 & 312 \\
\hline 12 & $\mathrm{~L}$ & 0 & 0 & 336 & 0 & 0 & 332 & 0 & 0 & 0 & 0 & 668 \\
\hline 13 & $\mathrm{M}$ & 965 & 0 & 0 & 0 & 1.475 & 0 & 0 & 0 & 0 & 0 & 2.440 \\
\hline 14 & $\mathrm{~N}$ & 0 & 695 & 0 & 0 & 0 & 690 & 0 & 0 & 0 & 0 & 1.385 \\
\hline 15 & 0 & 0 & 0 & 900 & 0 & 715 & 0 & 0 & 0 & 0 & 0 & 1.615 \\
\hline 16 & P & 105 & 0 & 0 & 100 & 0 & 0 & 0 & 0 & 0 & 0 & 205 \\
\hline 17 & $\mathrm{Q}$ & 5 & 0 & 0 & 35 & 0 & 0 & 0 & 0 & 0 & 0 & 40 \\
\hline 18 & $R$ & 0 & 333 & 0 & 0 & 0 & 318 & 0 & 0 & 0 & 0 & 651 \\
\hline 19 & S & 0 & 0 & 0 & 15 & 0 & 0 & 0 & 0 & 0 & 0 & 15 \\
\hline 20 & $\mathrm{~T}$ & 0 & 0 & 0 & 315 & 0 & 0 & 0 & 0 & 0 & 0 & 315 \\
\hline 21 & U & 0 & 0 & 1.200 & 0 & 0 & 1.295 & 0 & 0 & 0 & 0 & 2.495 \\
\hline 22 & V & 0 & 0 & 72 & 0 & 0 & 73 & 0 & 0 & 0 & 0 & 145 \\
\hline 23 & W & 0 & 0 & 0 & 69 & 0 & 0 & 0 & 0 & 0 & 0 & 69 \\
\hline 24 & $x$ & 0 & 44 & 0 & 0 & 0 & 65 & 0 & 0 & 0 & 0 & 109 \\
\hline 25 & z & 230 & 0 & 0 & 0 & 70 & 0 & 0 & 0 & 0 & 0 & 300 \\
\hline 26 & AA & 0 & 235 & 0 & 0 & 0 & 35 & 0 & 0 & 0 & 0 & 270 \\
\hline 27 & BB & 420 & 0 & 0 & 0 & 70 & 0 & 0 & 0 & 0 & 0 & 490 \\
\hline 28 & $\mathrm{CC}$ & 0 & 440 & 0 & 0 & 0 & 0 & 0 & 0 & 0 & 0 & 440 \\
\hline 29 & DD & 0 & 1.190 & 0 & 0 & 1.765 & 0 & 0 & 0 & 0 & 0 & 2.955 \\
\hline 30 & $\mathrm{EE}$ & 1.395 & 0 & 0 & 0 & 1.240 & 0 & 0 & 0 & 0 & 0 & 2.635 \\
\hline 31 & $\mathrm{FF}$ & 0 & 695 & 0 & 0 & 0 & 620 & 0 & 0 & 0 & 0 & 1.315 \\
\hline 32 & GG & 0 & 0 & 940 & 0 & 0 & 0 & 0 & 0 & 0 & 0 & 940 \\
\hline 33 & $\mathrm{HH}$ & 0 & 0 & 1.365 & 0 & 0 & 0 & 0 & 0 & 0 & 0 & 1.365 \\
\hline
\end{tabular}

\section{Gambar 5. Order List}

Pada order list diketahui bahwa pada item B harus dilakukan pemesanan sebanyak 3 kali yaitu pada minggu persiapan material yang dipesan sebanyak $335 \mathrm{~kg}$, minggu ke-2 sebanyak $295 \mathrm{~kg}$ dan pada minggu ke- 5 sebanyak $265 \mathrm{~kg}$.

\section{Analisa Biaya berdasarkan Teknik Pemesanan}

\section{Tabel 2. Perbandingan Total Biaya}

\begin{tabular}{ll}
\hline Teknik Lot Sizing & Total Biaya \\
\hline Part Period Balancing & $\mathrm{Rp} 31.879 .750,00$ \\
Lot for Lot & $\mathrm{Rp} 22.918 .150,00$ \\
Economic Order Quantity & $\mathrm{Rp} 23.565 .365,54$ \\
\hline
\end{tabular}

Dengan membandingkan biaya pada setiap teknik lot sizing yang berbeda, diperoleh bahwa penentuan ukuran pemesanan menggunakan teknik Lot for Lot akan memerlukan total biaya yang terkecil dibandingkan teknik PPB dan EOQ. 


\section{Simpulan dan Saran \\ Simpulan}

Berdasarkan hasil penelitian terhadap kebutuhan material proyek steel structure menggunakan teknik lot sizing Lot for Lot, Part Periode Balancing, dan Economic order Quantity maka dapat disimpulkan :

1. Ukuran pemesanan material proyek steel structure menggunakan teknik lot for lot akan memberikan hasil yang optimum dengan biaya yang diperlukan paling rendah yaitu sebesar Rp. 22.918.150,00.

2. Dengan melakukan analisa dalam penentuan ukuran pemesanan material dapat membentuk biaya persediaan yang minimal.

3. Penggunaan teknik lot sizing yang tepat dapat meminimalkan resiko terjadinya keterlambatan material.

4. Penjadwalan kebutuhan material yang diterapkan secara komputerisasi menggunakan software WinQsb ini sangat membantu perusahaan dalam memonitor kebutuhan material dan data inventory material.

\section{Saran}

Saran yang disampaikan dari hasil penelitian ini adalah bahwa dalam penelitian ini masih banyak kekurangan diantaranya:

1. Peneliti hanya menguji teknik pemesanan Lot For Lot,Part Periode Balancing, dan Economic Order Quantity.

2. Pada penelitian selanjutnya diharapkan bisa menggunakan teknik ukuran pemesanan yang lain.

\section{Daftar Pustaka}

Abrar, H. (2011). Manajemen Proyek. Yogyakarta: ANDI.

Assauri, S.(2008). Manajemen Produksi dan Operasi. Edisi 4. Jakarta : Lembaga Penerbit Fakultas Ekonomi Universitas Indonesia.

Heizer, J. dan Render, B. (2005). Manajemen Operasi. Edisi Tujuh. Jakarta: Salemba Empat.

Limbong, I. dan Walangitan, D. R. O. , Tarore,H., Tjakra, J. (2013). Manajemen Pengadaan Material Bangunan Dengan Menggunakan Metode MRP Studi Kasus : Revitalisasi Gedung Kantor BPS Propinsi Sulawesi Utara. Jurnal Sipil Statik, Vol.1 No.6 Mei 2013 (421-429)

Nasution, A.H. (2006). Manajemen Industri. Yogyakarta : PT Andi

Paath, P.C. dan Tjakra, J. (2015). Analisis Pengendalian Bahan Proyek Pembangunan Dengan Metode Goal Programming Prioritas ( STudi Kasus: Proyek Pembangunan Gedung Sekolah Eben Haezar ). Jurnal Sipil Statik, Vol.3 No.5 Mei 2015 (351-360)

Sanfishdah Putria W, (2012. Perancangan Aplikasi Material Requirement Planning (MRP) dengan Metode Goal Programming. Surabaya:Institut Teknologi Sepuluh Nopember.

Siswanto. (2006). Operational Research. Jakarta: Erlangga

Tarore, H. dan Mandagi, R.J.M. (2006). Sistem Manajemen Proyek dan Konstruksi (SIMPROKON). JTS Fakultas Teknik Universitas Sam Ratulangi Manado. 